\title{
Metode Altman Z-Score dalam Memprediksi Kepailitan di Semua Koperasi Kredit di Kabupaten Maumere
}

\author{
Yoseph Darius Purnama Rangga ${ }^{1)}$ Henrikus Herdi ${ }^{2)}$ Wilhelmina Mitan ${ }^{3)}$ \\ ${ }^{1,2,3}$ Fakultas Ekonomi/Akuntansi, Universitas Nusa Nipa Maumere \\ *Email korespondensi:jo.darius1206@gmail.com
}

Problems that often occur in a cooperative are usually caused by financial problems. To measure the level of financial health cooperatives can be used analysis of financial ratios using the Altman Z-Score model. This research aims to predict bankruptcy in the credit Union of the regional government Puskopdit, Maumere, using the Altman Z-Score model. The samples in this study were credit cooperatives of the main district Puskopdit in 2015-2017 consisting of 16 cooperatives. The data source used is the secondary data in the form of cooperative financial statements. The analytical technique used is the Altman Z-Score Bankruptcy Prediction model. The results showed that there is a cooperative that has been in the healthy category during the year 2015-2017, namely Torch Mas Cooperative, Tuke Jung, Ortal, Plantation, star East, and Serba Te. In the years 2015 and 2016 Kelubagolit cooperatives entered in the category of gray area, but in the year 2017 the cooperative is in a healthy category. In addition, there are cooperatives during the year 2015-2017 in the category of gray area namely Sube Huter Cooperative, Tuke Ler, Hiro Heling, Bina Pertiwi, and Surya Sakti. The cooperatives of San Dominggo in 2015 and 2016 were in the category of bankruptcy, but the following year entered the gray area category. The cooperative in the category of bankruptcy from 2015-2017 is the youth cooperative Hokeng and Ankara. In the year 2015 Plelu Meluk Cooperative entered in the category of gray area, the cooperative's performance continued to decline and in the year 2016 and 2017 the cooperative was entered in the category of bankruptcy. In the years 2018, Hokeng Youth Cooperative experienced an amalgamation with Mitan Gitan Cooperative. This indicates that the accuracy level of the Altman Z-Score model is high..

Keywords : Altman Z-Score, co-operative credit, bankruptcy

Saran sitasi: Rangga, Y. D. P., Herdi, H., \& Mitan, W. (2020). Metode Altman Z-Score dalam Memprediksi Kepailitan di Semua Koperasi Kredit di Kabupaten Maumere. Jurnal Akuntansi dan Pajak, 21 (1), 59-70. doi:http://dx.doi.org/10.29040/jap.v21i1.1097

DOI: http://dx.doi.org/10.29040/jap.v21i1.1097

\section{PENDAHULUAN}

Kesehatan kinerja koperasi sebaiknya diprediksi sedini mungkin agar tidak mengalami keadaaan kesulitan keuangan (financial distress) yang berkelanjutan, dimana nantinya akan mengarah kepada koperasi tidak aktif dan akhirnya harus dibubarkan oleh pihak yang berwenang. Financial distress adalah keadaan kesulitan keuangan atau likuiditas yang mungkin merupakan awal dari terjadinya kebangkrutan (Gamayuni, 2011:165). Manajer berkepentingan untuk mengambil langkahlangkah yang tepat untuk memperbaiki kondisi keuangan koperasi serta meminimalisir kemungkinan terjadinya kondisi keuangan yang lebih buruk. Halhal tersebut akan menggiring keuangan koperasi pada kondisi financial distress yang jika tidak segera diperbaiki maka dapat berujung pada kebangkrutan koperasi. Sehingga kebangkrutan menjadi suatu masalah yang sangat esensial yang perlu selalu diwaspadai dan diantisipasi oleh koperasi. Sebagai contoh fenomena yang terjadi saat ini adalah pada koperasi Remaja Hokeng. Pada tahun 2018 koperasi Remaja Hokeng dibawah naungan Puskopdit Swadaya Utama mengalami amalgamasi dan bergabung dengan koperasi Mitan Gitan, hal ini disebabkan karena beberapa faktor yang terjadi salah satunya adalah terjadinya penyimpangan internal.

Kebangkrutan adalah kegagalan perusahaan dalam menjalankan operasi perusahaan untuk menghasilkan laba (Supardi dan Mastuti, 2003:79). 
Kondisi kebangkrutan biasanya tidak muncul begitu saja di koperasi. Ada indikasi awal dari koperasi tersebut yang biasanya dapat dikenali lebih awal jika laporan keuangan dianalisis secara lebih cermat dengan menggunakan model prediksi yang dapat memberikan peringatan dini.

Indikasi potensi kebangkrutan dapat diidentifikasi lebih awal sebelum terlambat dengan menggunakan model prediksi yang dapat memberikan peringatan awal. Hal ini dikarenakan dampak yang ditimbulkan oleh kebangkrutan tidak hanya dapat merugikan pihak manajemen, akan tetapi juga seluruh pihak yang bersangkutan dengan perusahaan tersebut (Suharto, 2015:6). Beberapa ilmuwan telah merumuskan model-model prediksi yang dapat membantu para manajer dalam upaya mengantisipasi terjadinya kondisi kebangkrutan, diantaranya adalah model Altman Z-Score.

Model Altman Z-Score pertama kali diperkenalkan oleh Altman pada tahun 1968. Altman menciptakan model dengan menggunakan sejumlah rasio dalam laporan keuangan dan menganalisis beberapa diskriminan untuk memprediksi kebangkrutan perusahaan (Claudio dan Ponto, 2015:19). Hasil dari penelitian yang di lakukan oleh Sinaga (2012), Widiyawati, dkk (2015), Ningsih dan Permatasari (2018) serta Gamayuni (2011) menunjukkan bahwa model Altman Z-Score dapat digunakan dalam mendeteksi potensi terjadinya kebangkrutan. Kartikawati (2009) secara metodologi penggunaan model Altman Z-Score dapat mengidentifikasi keadaan suatu perusahaan, namun secara faktual terkadang tidak sesuai dengan kenyataan yang terjadi saat ini.

Berdasarkan hasil penelitian terdahulu menunjukkan adanya perbedaan hasil penelitian dalam memprediksi kebangkrutan dengan beberapa model Altman Z-Score. Oleh karena itu, mendorong peneliti untuk melakukan penelitian kembali dengan menggunakan model Altman Z-Score dengan obyek yang berbeda yaitu pada perusahaan jasa yaitu seluruh koperasi yang ada di Kabupaten Maumere.

Untuk meningkatkan daya saing, koperasi membutuhkan suatu pengendalian manajemen yang baik untuk mencapai tujuannya, serta laporan keuangan untuk dijadikan sebagai informasi kinerja koperasi agar dapat bersaing dengan koperasikoperasi lain agar terhindar dari kebangkrutan. Berdasarkan uraian di atas, maka judul penelitian ini adalah "Analisis Prediksi Kebangkrutan Dengan Menggunakan Model Altman Z-Score Pada Koperasi
Kredit Sewilayah Puskopdit Swadaya Utama Tahun 2015-2017".

\section{Telaah Teori}

\section{Analisis Laporan Keuangan}

Analisis laporan keuangan berarti menguraikan pos-pos laporan keuangan menjadi unit informasi yang lebih kecil dan melihat hubungannya signifikan atau yang mempunyai makna antara satu dengan yang lain baik antara data kuantitaf maupun data nonkuantitatif dengan tujuan untuk mengetahui kondisi keuangan lebih dalam yang sangat penting dalam proses menghasilkan keputusan yang tepat (Harahap, 2011:190).

\section{Financial Distress}

Ramadhani dan Lukviarman

(2009:17) menyimpulkan bahwa financial distress adalah suatu situasi dimana arus kas operasi perusahaan tidak memadai untuk melunasi kewajiban-kewajiban lancar (seperti hutang dagang atau beban bunga) dan perusahaan terpaksa melakukan tindakan perbaikan. Jadi pada dasarnya kebangkrutan adalah semua resiko yang berhubungan dengan ketidakjelasan terhadap kemampuan dalam suatu perusahaan untuk melanjutkan kegiatan operasinya jika terjadi penurunan terhadap kondisi keuangan yang dimiliki dan biasanya indikator terjadinya kebangkrutan biasanya ditandai oleh berbagai situasi atau keadaan khususnya yang berhubungan dengan efektivitas dan efisiensi operasinya.

\section{Model Altman Z-Score}

Perkembangan model Altman ini dapat dilihat mulai dari yang pertama yaitu model Altman Z-Score pertama yang ditujukan untuk memprediksi kebangkrutan dari sebuah perusahaan manufaktur. Setelah menemukan emukan model Altman revisi Selanjutnya Altman memodifikasi modelnya agar dapat diterapkan pada perusahaan jasa seperti koperasi dan bank, model ini disebut sebagai model Altman modifikasi dengan menggunakan empat rasio yang terdiri dari :

a. Rasio Modal Kerja Terhadap Total Aktiva (X1). Rasio ini menunjukkan kemampuan koperasi untuk menghasilkan modal kerja bersih dari keseluruhan total aktiva yang dimiliki. Rasio ini dihitung dengan membagi modal kerja bersih dengan total aktiva. Modal kerja bersih diperoleh dengan cara aktiva lancar dikurangi dengan kewajiban lancar. 


\section{Jurnal Akuntansi dan Pajak, 21 (01), 2020, 61}

b. Rasio SHU Ditahan Terhadap Total Aktiva (X2). Rasio ini menunjukkan kemampuan koperasi untuk menghasilkan SHU ditahan dari total aktiva koperasi. SHU ditahan merupakan SHU yang tidak dibagikan kepada para anggota koperasi.

c. Rasio EBIT Terhadap Total Aktiva (X3). Rasio ini menunjukkan kemampuan koperasi untuk menghasilkan SHU dari aktiva koperasi sebelum pembayaran bunga dan pajak.

d. Rasio Nilai Buku Ekuitas Terhadap Total Hutang (X4). Rasio yang digunakan untuk mengukur sejauh mana aktiva koperasi dibiayai dari hutang. Artinya berapa besar beban hutang yang ditanggung koperasi dibandingkan dengan aktivanya. Dalam arti luas dikatakan bahwa rasio ini digunakan untuk mengukur kemampuan koperasi untuk membayar seluruh kewajibannya, baik jangka pendek maupun jangka panjang apabila koperasi dibubarkan atau dilikuidasi.

\section{METODE PENELITIAN}

Penelitian ini menggunakan pendekatan deskriptif kuantitatif karena data dalam penelitian ini adalah angka-angka dalam laporan keuangan koperasi dimana tempat penelitian pada Pusat Koperasi Kredit (Puskopdit) Swadaya Utama yang beralamat di Jln. Wairklau, Kel. Kota Uneng, Kec. Alok, Kab. Sikka, Maumere - Flores - Nusa Tenggara Timur.

\section{Populasi dan Sampel}

Populasi dari penelitian ini adalah koperasikoperasi kredit sewilayah Puskopdit Swadaya Utama dengan jumlah populasi sebanyak 38 koperasi sedangkan sampel yang digunakan dalam penelitian ini adalah koperasi-koperasi kredit sewilayah Puskopdit Swadaya Utama Maumere yang menerbitkan laporan keuangan sejak tahun 2015 sampai dengan tahun 2017 dimana sampel dalam penelitian berjumlah 16 koperasi.

\section{Analisis Data}

Kegiatan dalam analisis data adalah mengelompokan data berdasarkan variabel dan jenis responden, tabulasi data berdasarkan variabel dari seluruh responden, menyajikan data dari setiap variabel yang diteliti, melakukan perhitungan untuk menjawab rumusan masalah dan melakukan perhitungan untuk melakukan hipotesis yang telah diajukan.
Metode analisis dalam penelitian ini adalah analisis akuntansi berupa model Altman Z-Score. Pada teknik ini data akan dianalisis menggunakan perhitungan angka- angka dari laporan keuangan, seperti neraca dan laba rugi yang kemudian digunakan sebagai dasar pengambilan keputusan. Teknik analisa yang digunakan dalam penelitian ini adalah rumusan dari model Altman Z-Score sebagai berikut (Nugroho, 2011:25-27):

a. Menghitung beberapa rasio keuangan koperasi yang terdapat dalam sampel penelitian ini:

1) Rasio Modal Kerja terhadap Total Aktiva (X1)

$$
X 1=\frac{\text { Modal Kerja }}{\text { Total Aktiva }}
$$

2) Rasio SHU Ditahan terhadap Total Aktiva (X2)

$$
X 2=\frac{\text { SHU Ditahan }}{\text { Total Aktiva }}
$$

3) Rasio EBIT terhadap Total Aktiva (X3)

$$
X 3=\frac{E B I T}{\text { Total Aktiva }}
$$

4) Rasio Nilai Buku Ekuitas terhadap Total Hutang (X4)

$$
X 4=\frac{\text { Nilai Buku Ekuitas }}{\text { Total Hutang }}
$$

b. Data atau hasil perhitungan rasio keuangan kemudian dianalisis dengan menggunakan formula yang ditemukan oleh Altman yaitu:

$$
Z=6,56\left(x_{1}\right)+3,26\left(x_{2}\right)+6,72\left(x_{3}\right)+1,05
$$

\section{Dimana:}

$\mathrm{X} 1=$ Rasio Modal Kerja terhadap Total Aktiva

X2 = Rasio SHU Ditahan terhadap Total Aktiva

$\mathrm{X} 3$ = Rasio EBIT terhadap Total Aktiva terhadap Total Hutang

X4 = Rasio Nilai Buku Ekuitas

c. Mengklasifikasikan masing-masing sampel penelitian berdasarkan kriteria- kriteria kebangkrutan. Kriteria-kriteria kebangkrutan menurut Altman adalah sebagai berikut:

1) Jika $\mathrm{Zi}>2,6:$ merupakan kategori dalam keadaan sehat.

2) Jika $\mathrm{Zi}<1,1$ : merupakan kategori dalam keadaan bangkrut.

3) Jika $\mathrm{Zi}$ diantara 1,1-2,6 : merupakan kategori gray area.

d. Melakukan analisis sehingga memperoleh kesimpulan mengenai kinerja koperasi dan 
prediksi terhadap kebangkrutan koperasi tersebut.

\section{HASIL DAN PEMBAHASAN}

\section{Hasil Penelitian}

Berikut peneliti tampilkan hasil dari penelitian ini:

\section{a. Koperasi Obor Mas}

Tabel 3.1

Hasil Perhitungan Z-Score

Koperasi Obor Mas Tahun 2015-2017

\begin{tabular}{|l|l|l|l|}
\hline \multicolumn{1}{|c|}{ Rasio } & \multicolumn{1}{|c|}{$\mathbf{2 0 1 5}$} & \multicolumn{1}{c|}{$\mathbf{2 0 1 6}$} & \multicolumn{1}{c|}{$\mathbf{2 0 1 7}$} \\
\hline X1 & 0,4961 & 0,5317 & 0,5075 \\
\hline X2 & 0,0056 & 0,0056 & 0,0055 \\
\hline X3 & 0,0073 & 0,0072 & 0,0070 \\
\hline X4 & 0,2982 & 0,3451 & 0,3797 \\
\hline Z-Score & 3,635 & 3,917 & 3,793 \\
\hline
\end{tabular}

Sumber: data diolah, 2019

Berdasarkan tabel 1. di atas menunjukkan bahwa selama tiga tahun berturut-turut koperasi Obor Mas tetap berada dalam posisi sehat. Peningkatan nilai $\mathrm{Z}$ dari tahun 2015 ke 2016 diikuti dengan meningkatnya nilai rasio $\mathrm{X} 1$ dan $\mathrm{X} 4$ yang menunjukkan kemampuan koperasi untuk menghasilkan modal kerja bersih dari keseluruhan total aktiva yang dimiliki dan sejauh mana aktiva koperasi dibiayai dari hutang. Artinya berapa besar beban hutang yang ditanggung koperasi dibandingkan dengan aktivanya. Sedangkan rasio X2 memiliki nilai tetap dan $\mathrm{X} 3$ mengalami penurunan

\section{b. Koperasi Ankara}

Berdasarkan tabel 2. di bawah ini hasil penelitan menunjukkan bahwa selama tiga tahun berturut-turut koperasi Ankara berada dalam posisi bangkrut hal ini tentu sangat membahayakan koperasi.

Tabel 3.2.

Hasil Perhitungan Z-Score

Koperasi Ankara Tahun 2015-2017

\begin{tabular}{|l|l|l|l|}
\hline \multicolumn{1}{|c|}{ Rasio } & \multicolumn{1}{|c|}{$\mathbf{2 0 1 5}$} & \multicolumn{1}{c|}{$\mathbf{2 0 1 6}$} & \multicolumn{1}{c|}{$\mathbf{2 0 1 7}$} \\
\hline X1 & 0,0596 & 0,053 & 0,0883 \\
\hline X2 & 0,0056 & 0,0031 & 0,0038 \\
\hline X3 & 0,0091 & 0,0046 & 0,0043 \\
\hline X4 & 0,1706 & 0,1736 & 0,1865 \\
\hline Z-Score & 0,65 & 0,571 & 0,817 \\
\hline
\end{tabular}

Sumber: data diolah 2019

Penurunan nilai Z dari tahun 2015 ke 2016 diikuti dengan menurunnya nilai rasio $\mathrm{X} 1, \mathrm{X} 2$, dan X3 sedangkan X4 mengalami peningkatan. Penurunan yang lebih dominan terjadi pada rasio X1 yang menandakan koperasi kurang efisien dalam menghasilkan modal kerja bersih dari keseluruhan aktiva.

Pada tahun 2017 koperasi Ankara mengalami peningkatan nilai $\mathrm{Z}$ menjadi 0,817 namun tetap berada dalam kondisi bangkrut. Hal ini di sebabkan karena meningkatnya rasio $\mathrm{X} 1, \mathrm{X} 2$, dan $\mathrm{X} 4$, sedangkan X3 mengalami penurunan yang menunjukkan kemampuan koperasi untuk menghasilkan SHU dari aktiva koperasi sebelum membayar pajak yang pada tahun sebelumnya juga mengalami penurunan.

\section{c. Koperasi Remaja Hokeng}

Tabel 3.3

Hasil Perhitungan Z-Score

Koperasi Remaja Hokeng 2015-2017

\begin{tabular}{|l|l|l|l|}
\hline \multicolumn{1}{|c|}{ Rasio } & \multicolumn{1}{c|}{$\mathbf{2 0 1 5}$} & \multicolumn{1}{c|}{$\mathbf{2 0 1 6}$} & \multicolumn{1}{c|}{$\mathbf{2 0 1 7}$} \\
\hline X1 & 0,1914 & $-0,0252$ & $-0,0718$ \\
\hline X2 & $-0,071$ & 0,0018 & $-0,0017$ \\
\hline X3 & $-0,0697$ & 0,0019 & $-0,0017$ \\
\hline X4 & 0,1548 & 0,2152 & 0,1258 \\
\hline Z-Score & 0,719 & 0,079 & $-0,353$ \\
\hline
\end{tabular}

Sumber : data diolah 2019

Sama dengan koperasi Ankara, selama tiga tahun berturut-turut juga koperasi Remaja Hokeng berada pada posisi bangkrut. Nilai $Z$ dari tahun 2015-2017 terus mengalami penurunan. Penurunan nilai $\mathrm{Z}$ dari tahun 2015 ke 2016 di sebabkan karena rasio X1 mengalami penurunan yang menandakan koperasi kurang efisien dalam menghasilkan modal kerja bersih dari keseluruhan aktiva yang dimiliki koperasi. Sedangkan rasio $\mathrm{X} 2, \mathrm{X} 3$, dan $\mathrm{X} 4$ mengalami peningkatan. Tahun 2017 nilai $\mathrm{Z}$ terus menurun dengan nilai $Z-0,353$ diikuti dengan menurunnya rasio $\mathrm{X} 2, \mathrm{X} 3$, dan $\mathrm{X} 4$ dan yang mendominasi penurunan adalah rasio $\mathrm{X} 4$ yang membuktikan adanya beban hutang yang ditanggung koperasi dibandingkan dengan aktiva yang dimiliki koperasi

\section{d. Koperasi Tuke Ler}

Tabel 3.4.

Hasil Perhitungan Z-Score

Koperasi Tuke Ler Tahun 2015-2017

\begin{tabular}{|l|l|l|l|}
\hline \multicolumn{1}{|c|}{ Rasio } & \multicolumn{1}{c|}{$\mathbf{2 0 1 5}$} & \multicolumn{1}{c|}{$\mathbf{2 0 1 6}$} & \multicolumn{1}{c|}{$\mathbf{2 0 1 7}$} \\
\hline X1 & 0,2119 & 0,2711 & 0,2463 \\
\hline X2 & 0,0067 & 0,0047 & 0,0030 \\
\hline X3 & 0,0082 & 0,0059 & 0,0037 \\
\hline X4 & 0,4561 & 0,3837 & 0,4198 \\
\hline Z-Score & 1,946 & 2,236 & 2,091 \\
\hline
\end{tabular}

Sumber: data diolah 2019 
Hasil penelitian tabel 4. di atas menunjukkan bahwa selama tiga tahun berturut-turut koperasi Tuke Ler mengalami posisi gray area. Peningkatan nilai $Z$ Score dari tahun 2015 ke tahun 2016 diikuti peningkatan rasio $\mathrm{X} 1$ yang membuktikan peningkatan kemampuan koperasi dalam menghasilkan modal kerja bersih dari keseluruhan aktiva yang dimiliki koperasi. Sedangkan rasio X2, $\mathrm{X} 3$, dan X4 mengalami penurunan dan yang lebih dominan mengalami penurunan adalah $\mathrm{X} 4$ yang membuktikan adanya penurunan beban hutang yang ditanggung koperasi dibandingkan dengan aktivanya.

Pada tahun 2017 nilai Z-Score terus mengalami penurunan menjadi 2,091 dan masih dalam posisi gray area. Penuruan terjadi karena menurunnya rasio $\mathrm{X} 1, \mathrm{X} 2$, dan $\mathrm{X} 3$ dan rasio $\mathrm{X} 1$ lebih dominan yang menandakan koperasi kurang efisien dalam menghasilkan modal kerja bersih dari keseluruhan aktiva. Apabila koperasi bisa terus memperbaiki kinerjanya dan terus meningkatkan nilai koperasi maka tahun-tahun yang akan datang ada kemungkinan perusahaan bisa berada dalam posisi sehat. Selain itu juga, koperasi harus meningkatkan modal kerja bersih, SHU di tahan, dan SHU sebelum pajak sehingga pada tahun berikutnya dapat keluar dari posisi gray area.

\section{e. Koperasi Sube Huter}

Tabel 3.5.

Hasil Perhitungan Z-Score

Koperasi Sube Huter Tahun 2015-2017

\begin{tabular}{|l|l|l|l|}
\hline \multicolumn{1}{|c|}{ Rasio } & \multicolumn{1}{c|}{$\mathbf{2 0 1 5}$} & \multicolumn{1}{c|}{$\mathbf{2 0 1 6}$} & \multicolumn{1}{c|}{$\mathbf{2 0 1 7}$} \\
\hline $\mathrm{X} 1$ & 0,1286 & 0,1443 & 0,1567 \\
\hline $\mathrm{X} 2$ & 0,0107 & 0,0124 & 0,0114 \\
\hline $\mathrm{X} 3$ & 0,0112 & 0,0124 & 0,012 \\
\hline $\mathrm{X} 4$ & 0,2526 & 0,2627 & 0,2461 \\
\hline Z-Score & 1,219 & 1,346 & 1,404 \\
\hline
\end{tabular}

Sumber: data diolah, 2019

Dari tabel 5. hasil perhitungan nilai Z-Score dapat dilihat bahwa Koperasi Sube Huter selama tiga tahun berturut-turut berada dalam kategori gray area. Pada tahun 2015 dengan nilai Z-Score yaitu 1,219 dengan peningkatan seluruh rasio, pada tahun 2016 maka nilai $Z$-Score meningkat menjadi 1,346 . Rasio $\mathrm{X} 1$ adalah rasio yang mengalami peningkatan yang mendominasi artinya koperasi mengalami peningkatan kemampuan dalam menghasilkan modal bersih. Peningkatan nilai Z-Score juga terjadi pada tahun 2017 tetapi koperasi masih tetap dalam kategori gray area yang mempengaruhi peningkatan yaitu rasio X1 yang tahun sebelumnya mengalami peningkatan, hal ini dapat menggambarkan modal kerja bersih dari keseluruhan aktiva telah berjalan secara efisien. Koperasi juga harus meningkatkan SHU di tahan, SHU sebelum pajak, dan meningkatkan kewajiban-kewajiban sehingga pada tahun berikutnya dapat keluar dari posisi gray area.

\section{f. Koperasi Tuke Jung}

Tabel 3.6.

Hasil Perhitungan Z-Score

Koperasi Tuke Jung Tahun 2015-2017

\begin{tabular}{|l|l|l|l|}
\hline \multicolumn{1}{|c|}{ Rasio } & \multicolumn{1}{c|}{$\mathbf{2 0 1 5}$} & \multicolumn{1}{c|}{$\mathbf{2 0 1 6}$} & \multicolumn{1}{c|}{$\mathbf{2 0 1 7}$} \\
\hline $\mathrm{X} 1$ & 0,3995 & 0,4043 & 0,4282 \\
\hline $\mathrm{X} 2$ & 0,0128 & 0,0124 & 0,0069 \\
\hline $\mathrm{X} 3$ & 0,0147 & 0,0141 & 0,0086 \\
\hline X4 & 0,2253 & 0,2398 & 0,2512 \\
\hline Z-Score & 2,998 & 3,039 & 3,153 \\
\hline
\end{tabular}

Sumber: data diolah, 2019

Tabel 6. di atas menggambarkan hasil perhitungan Z-Score koperasi Tuke Jung untuk tahun 2015-2017. Hasil penelitian menunjukkan bahwa selama tiga tahun berturut-turut koperasi mengalami kategori sehat. Peningkatan dari tahun 2015-2017 diikuti peningkatan rasio $\mathrm{X} 1$ dan $\mathrm{X} 4$ yang menandakan koperasi mampu menghasilkan modal kerja bersih dari keseluruhan total aktiva yang dimiliki dan sejauh mana aktiva koperasi dibiayai dari hutang.

\section{g. Koperasi Hiro Heling}

Tabel 3.7

Hasil Perhitungan Z-Score

Koperasi Hiro Heling Tahun 2015-2017

\begin{tabular}{|l|l|l|l||}
\hline \multicolumn{1}{|c|}{ Rasio } & \multicolumn{1}{c|}{$\mathbf{2 0 1 5}$} & \multicolumn{1}{c|}{$\mathbf{2 0 1 6}$} & \multicolumn{1}{c|}{$\mathbf{2 0 1 7}$} \\
\hline $\mathrm{X} 1$ & 0,3235 & 0,2922 & 0,1739 \\
\hline $\mathrm{X} 2$ & 0,0003 & 0,0118 & 0,0068 \\
\hline $\mathrm{X} 3$ & 0,010 & 0,0084 & 0,0086 \\
\hline $\mathrm{X} 4$ & 0,2928 & 0,3120 & 0,3259 \\
\hline Z-Score & 2,498 & 2,339 & 1,563 \\
\hline
\end{tabular}

Sumber: data diolah, 2019

Tabel 7 di atas menjelaskan bahwa hasil perhitungan analisis Z-Score pada tahun 2015 koperasi Hiro Heling mempunyai nilai $Z$ sebesar 2,498 yang termasuk dalam kategori gray area, pada tahun 2016 koperasi juga berada dalam kategori yang sama yaitu gray area dan terjadi penurunan menjadi 2,339. Penurunan yang paling dominan adalah X1 hal 


\section{Jurnal Akuntansi dan Pajak, 21 (01), 2020, 64}

ini mencerminkan bahwa koperasi mengalami penurunan yang tinggi menandakan bahwa kondisi likuiditas yang semakin buruk karena modal kerjanya menyusut secara relatif terhadap total aktivanya.

Penurunan nilai $\mathrm{Z}$ pada tahun 2016 juga disertai adanya peningkatan pada X2 dan X4 yang menunjukkan bahwa perusahaan semakin baik dalam menghasilkan SHU ditahan dari total aktiva dan menujukan kemampuan koperasi dalam membiayai aktiva dari total hutang yang dimiliki. Tahun 2017 nilai $\mathrm{Z}$ kembali turun menjadi 1,563 tetapi posisi perusahaan masih dalam gray area. Rasio yang dominan dalam penurunan ini yaitu rasio yang masih sama dari tahun sebelumnya yaitu X1.

\section{h. Koperasi Ortal}

Tabel 3.8.

Hasil Perhitungan Z-Score

Koperasi Ortal Tahun 2015-2017

\begin{tabular}{|l|l|l|l|}
\hline \multicolumn{1}{|c|}{ Rasio } & \multicolumn{1}{c|}{$\mathbf{2 0 1 5}$} & \multicolumn{1}{c|}{$\mathbf{2 0 1 6}$} & \multicolumn{1}{c|}{$\mathbf{2 0 1 7}$} \\
\hline $\mathrm{X} 1$ & 0,4474 & 0,4097 & 0,3495 \\
\hline $\mathrm{X} 2$ & 0,0071 & 0,0021 & 0,0020 \\
\hline $\mathrm{X} 3$ & 0,0068 & 0,0077 & $-0,0345$ \\
\hline $\mathrm{X} 4$ & 0,553 & 0,6158 & 0,5669 \\
\hline Z-Score & 3,584 & 3,393 & 2,663 \\
\hline
\end{tabular}

Sumber: data diolah, 2019

Selama tiga tahun berturut-turut koperasi masuk dalam kategori sehat dengan nilai $\mathrm{Z}$ ditahun 2015 yaitu 3,584, tahun 2016 yaitu 3,393 dan ditahun 2017 yaitu 2,663. Dapat dilihat penurunan dari tahun 20152017, rasio yang mempengaruhi penurunan tahun 2015 ke tahun 2016 adalah X1 dan X2 yang menandakan koperasi kurang efisien dalam menghasilkan modal kerja bersih dari keseluruhan aktiva serta menandakan bahwa pengadaan SHU ditahan sebagai sumber dana pengadaan aktiva kurang baik. Sedangkan rasio yang meningkat adalah rasio X3 dan X4. Untuk tahun 2017 semua rasio mengalami penurunan dan rasio dominan yang mengalami penurunan adalah rasio X1 yang tahun sebelumnya juga mengalami penurunan.

\section{i. Koperasi San Dominggo}

Tabel 3.9.

Hasil Perhitungan Z-Score

Koperasi San Dominggo Tahun 2015- 2017

\begin{tabular}{|l|l|l|l|}
\hline \multicolumn{1}{|c|}{ Rasio } & \multicolumn{1}{c|}{$\mathbf{2 0 1 5}$} & $\mathbf{2 0 1 6}$ & $\mathbf{2 0 1 7}$ \\
\hline $\mathrm{X} 1$ & 0,0726 & 0,0877 & 0,0924 \\
\hline $\mathrm{X} 2$ & 0,0120 & 0,0280 & 0,0354 \\
\hline $\mathrm{X} 3$ & 0,0134 & 0,0291 & 0,0367 \\
\hline
\end{tabular}

\begin{tabular}{|l|l|l|l|}
\hline X4 & 0,1409 & 0,1500 & 0,1715 \\
\hline Z-Score & 0,753 & 1,019 & 1,149 \\
\hline
\end{tabular}

Sumber: data diolah, 2019

Koperasi San Dominggo selama 2 tahun berturut-turut dalam kondisi bangkrut hal ini tentu sangat membahayakan koperasi, namun demikian terjadi peningkatan pada nilai Z-Score tahun 2016. Hal ini dikarenakan semua rasio mengalami peningkatan dan yang dominan mengalami peningkatan adalah rasio X1 dan X2 menggambarkan modal kerja bersih dari keseluruhan aktiva telah berjalan secara baik dan koperasi berhasil menghasilkan SHU ditahan dari total aktiva. Sedangkan ditahun 2017 koperasi berhasil keluar dari zona kebangkrutan karena semua rasio X mengalami peningkatan, sedangkan rasio yang berhasil meningkatkan nilai $\mathrm{Z}$ menjadi 1,149 untuk masuk dalam gray area adalah rasio X3 yang mengalami peningkatan dan hal ini menandakan bahwa koperasi berhasil meningkatkan kinerja perusahaan untuk menghasilkan SHU.

\section{j. Koperasi Plelu Meluk}

Tabel 3.10.

Hasil Perhitungan Z-Score

Koperasi Plelu Meluk Tahun 2015-2017

\begin{tabular}{|l|l|l|l||}
\hline \multicolumn{1}{|c|}{ Rasio } & \multicolumn{1}{c|}{$\mathbf{2 0 1 5}$} & \multicolumn{1}{c|}{$\mathbf{2 0 1 6}$} & \multicolumn{1}{c|}{$\mathbf{2 0 1 7}$} \\
\hline X1 & 0,1712 & 0,1123 & 0,1097 \\
\hline X2 & 0,0029 & 0,0023 & 0,0027 \\
\hline X3 & 0,0030 & 0,0029 & 0,0034 \\
\hline X4 & 0,2692 & 0,2561 & 0,2463 \\
\hline Z-Score & 1,435 & 1,032 & 1,010 \\
\hline
\end{tabular}

Sumber: data diolah, 2019

Hasil perhitungan analisis Z-Score di atas pada tabel 10. dapat dilihat bahwa pada tahun 2015 koperasi Plelu Meluk mempunyai nilai $\mathrm{Z}$ sebesar 1,435 yang artinya koperasi berada pada kategori gray area. Namun pada tahun 2016 nilai Z-Score semakin menurun menjadi 1,032 dan masuk dalam kategori bangkrut. Penyebab koperasi masuk dalam kategori bangkrut adalah semua rasio $\mathrm{X}$ mengalami penurunan, hal ini membuktikan bahwa koperasi masih belum secara maksimal untuk mengelola seluruh elemen keuangannya sehingga dapat berfungsi lebih baik agar terhindar dari kebangkrutan. Pada tahun 2017 nilai Z-Score terus menurun menjadi 1,010 dan koperasi tetap dalam kategori bangkrut, hal ini di sebabkan karena menurun rasio X1 dan X4, namun penurunan yang mendominasi adalah pada $\mathrm{X} 4$ yang pada tahun sebelumnya sempat mengalami 


\section{Jurnal Akuntansi dan Pajak, 21 (01), 2020, 65}

penurunan, hal ini menunjukkan bahwa koperasi kurang efektif dalam memenuhi kewajibankewajibannya.

\section{k. Koperasi Bina Pertiwi}

Tabel 3.11.

Hasil Perhitungan Z-Score

Koperasi Bina Pertiwi Tahun 2015-2017

\begin{tabular}{|l|l|l|l|}
\hline \multicolumn{1}{|r|}{ Rasio } & \multicolumn{1}{c|}{$\mathbf{2 0 1 5}$} & \multicolumn{1}{c|}{$\mathbf{2 0 1 6}$} & \multicolumn{1}{c|}{$\mathbf{2 0 1 7}$} \\
\hline $\mathrm{X} 1$ & 0,2126 & 0,1963 & 0,2324 \\
\hline $\mathrm{X} 2$ & 0,0036 & 0,0066 & 0,0061 \\
\hline $\mathrm{X} 3$ & 0,0053 & 0,0088 & 0,0085 \\
\hline $\mathrm{X} 4$ & 0,2426 & 0,2744 & 0,0085 \\
\hline Z-Score & 1,697 & 1,656 & 1,866 \\
\hline
\end{tabular}

Sumber : Data diolah, 2019

Tabel 11. di atas menggambarkan hasil perhitungan Z-Score koperasi Bina Pertiwi dari tahun 2015-2017. Hasil penelitian menunjukkan bahwa selama tiga tahun berturut-turut koperasi mengalami posisi gray area. Penurunan dari tahun 2015 ke tahun 2016 di sebabkan karena menurunnya rasio X1 dan $\mathrm{X} 2$ membuktikan adanya penurunan modal kerja bersih dalam menghasilkan SHU di tahan terhadap total aktiva. Penurunan rasio ini dijadikan sebagai tanda adanya indikator kebangkrutan.

Pada tahun 2017 nilai Z-Score meningkat menjadi 1,866 tetapi koperasi masih dalam zona gray area. Peningkatan tersebut di karenakan rasio X1 yang tahun sebelumnya mengalami penurunan dan pada tahun 2017 mengalami peningkatan yang cukup besar hal ini membuktikan bahwa koperasi meningkatkan modal kerja bersih dari total aktiva yang dimiliki koperasi.

\section{Koperasi Ladang}

Tabel 3.12.

Hasil Perhitungan Z-Score

Koperasi Ladang Tahun 2015-2017

\begin{tabular}{|l|l|l|l|}
\hline \multicolumn{1}{|c|}{ Rasio } & \multicolumn{1}{c|}{$\mathbf{2 0 1 5}$} & \multicolumn{1}{c|}{$\mathbf{2 0 1 6}$} & \multicolumn{1}{c|}{$\mathbf{2 0 1 7}$} \\
\hline $\mathrm{X} 1$ & 0,5910 & 0,5409 & 0,5415 \\
\hline $\mathrm{X} 2$ & 0,0170 & 0,0163 & 0,0128 \\
\hline $\mathrm{X} 3$ & 0,0181 & 0,0175 & 0,0140 \\
\hline $\mathrm{X} 4$ & 1,6013 & 1,5738 & 1,4957 \\
\hline Z-Score & 5,735 & 5,372 & 5,258 \\
\hline
\end{tabular}

Sumber : Data Diolah, 2019

Berdasarkan tabel 12. Diatas, secara berturutturut koperasi Ladang berada dalam posisi sehat dengan nilai $Z$-Score yaitu 5,735 ditahun 2015, 5,372 ditahun 2016, dan 5,258 ditahun 2017. Nilai $Z$ dari tahun 2015-2017 terus mengalami penurunan tetapi koperasi masih masuk dalam kategori sehat, hal yang menyebabkan nilai $\mathrm{Z}$ menurun adalah menurunnya rasio X2, X3, dan X4. Penurunan yang dominan adalah $\mathrm{X} 4$ yang menunjukkan koperasi tidak dengan efektif dalam memenuhi kewajiban-kewajibannya.

\section{m. Koperasi Bintang Timur}

Tabel 13

Hasil Perhitungan Z-Score Koperasi Bintang Timur Tahun 2015- 2017

\begin{tabular}{|l|l|l|l|}
\hline \multicolumn{1}{|c|}{ Rasio } & \multicolumn{1}{c|}{$\mathbf{2 0 1 5}$} & \multicolumn{1}{c|}{$\mathbf{2 0 1 6}$} & \multicolumn{1}{c|}{$\mathbf{2 0 1 7}$} \\
\hline $\mathrm{X} 1$ & 0,5520 & 0,5601 & 0,5182 \\
\hline $\mathrm{X} 2$ & 0,0076 & 0,0057 & 0,0078 \\
\hline $\mathrm{X} 3$ & 0,0076 & 0,0098 & 0,0119 \\
\hline $\mathrm{X} 4$ & 2,0646 & 2,1099 & 2,1022 \\
\hline Z-Score & 5,865 & 5,974 & 5,712 \\
\hline
\end{tabular}

Sumber: data diolah, 2019

Berdasarkan tabel $13 . \quad$ Diatas menunjukkan bahwa selama tiga tahun berturut-turut koperasi Bintang Timur tetap mempertahankan agar terus berada dalam kategori sehat. Peningkatan nilai Z dari 2015 ke tahun 2016 di sebabkan karena meningkatnya rasio $\mathrm{X} 1, \mathrm{X} 3$, dan $\mathrm{X} 4$ yang menandakan bahwa koperasi mampu menghasilkan modal kerja bersih yang besar dari keseluruhan total aktiva yang dimiliki sehingga mampu menghasilkan SHU dari aktiva koperasi sebelum pembayaran pajak, serta sejauh mana aktiva koperasi dibiayai dari hutang. Artinya berapa besar beban hutang yang ditanggung koperasi dibandingkan dengan aktivanya.

Pada tahun 2017 nilai $\mathrm{Z}$ menurun menjadi 5,712 tetap masih dalam kategori sehat. Berbalik dengan tahun sebelumnya, pada tahun 2017 rasio X1 dan X4 mengalami penurunan, ini di sebabkan karena kurangnya modal kerja bersih dalam menutupi kewajiban jangka pendeknya karena tidak tersedianya aktiva lancar yang cukup untuk menutupi kewajiban tersebut dan menunjukkan koperasi tidak dengan efektif dalam memenuhi kewajiban-kewajibannya.

\section{n. Koperasi Surya Sakti}

Tabel 3.14

Hasil Perhitungan Z-Score

Koperasi Surya Sakti Tahun 2015-2017

\begin{tabular}{|l|l|l|l|}
\hline \multicolumn{1}{|c|}{ Rasio } & \multicolumn{1}{c|}{$\mathbf{2 0 1 5}$} & \multicolumn{1}{c|}{$\mathbf{2 0 1 6}$} & \multicolumn{1}{c|}{$\mathbf{2 0 1 7}$} \\
\hline X1 & 0,1617 & 0,1669 & 0,1682 \\
\hline X2 & 0,0109 & 0,0077 & 0,0075 \\
\hline X3 & 0,0109 & 0,0077 & 0,0075 \\
\hline X4 & 0,4381 & 0,4579 & 0,4614 \\
\hline Z-Score & 1,629 & 1,653 & 1,662 \\
\hline
\end{tabular}


Sumber: data diolah, 2019

Berdasarkan tabel 14 hasil perhitungan nilai $Z$ Score koperasi Surya Sakti selama tahun 2015-2017 memiliki nilai $\mathrm{Z}$ yang terus meningkat tetapi masih masuk dalam kategori gray area. Peningkatan pada tahun 2015 ke tahun 2016 sama seperti yang terjadi pada koperasi Tuke Jung, peningkatan tersebut dikarenakan meningkatnya rasio X1 dan X4 yang menandakan koperasi mampu menghasilkan modal kerja bersih dari keseluruhan total aktiva yang dimiliki dan sejauh mana aktiva koperasi dibiayai dari hutang. Sedangkan penurunan nilai $\mathrm{Z}$ pada tahun 2017 yaitu 1,662 tetapi koperasi masih dalam kategori gray area karena rasio X1 memiliki nilai tetap, serta rasio $\mathrm{X} 4$ meningkat yang tahun sebelumnya juga meningkat. Dengan meningkatkan rasio lainnya dapat membuat koperasi pada tahun berikutnya masuk dalam kategori sehat.

\section{o. Koperasi Serba Te}

Tabel 3.15

Hasil Perhitungan Z-Score

Koperasi Serba Te Tahun 2015-2017

\begin{tabular}{|l|l|l|l|}
\hline \multicolumn{1}{|c|}{ Rasio } & \multicolumn{1}{c|}{$\mathbf{2 0 1 5}$} & \multicolumn{1}{c|}{$\mathbf{2 0 1 6}$} & \multicolumn{1}{c|}{$\mathbf{2 0 1 7}$} \\
\hline X1 & 0,5752 & 0,5809 & 0,5520 \\
\hline X2 & 0,0105 & 0,0130 & 0,0113 \\
\hline X3 & 0,0105 & 0,0130 & 0,0113 \\
\hline X4 & 2,3159 & 2,5654 & 2,2406 \\
\hline Z-Score & 6,310 & 6,634 & 6,087 \\
\hline
\end{tabular}

Sumber: data diolah, 2019

Berdasarkan tabel 15 di atas menunjukkan bahwa selama tiga tahun berturut-turut koperasi Serba Te tetap berada dalam posisi sehat. Pada tahun 2015 dengan nilai $Z$-Score yaitu 6,310 dengan peningkatan seluruh rasio pada tahun 2016 maka nilai Z- Score meningkat menjadi 6,634. Rasio X4 adalah rasio yang mengalami peningkatan yang mendominasi artinya koperasi mengalami peningkatan sejauh mana aktiva koperasi dibiayai dari hutang. Artinya berapa besar beban hutang yang ditanggung koperasi dibandingkan dengan aktivanya. Pada tahun 2017 nilai Z-Score mengalami penurunan menjadi 6,087 tetapi masih dalam kategori sehat. Penurunan disebabkan karena menurunnya semua rasio dan yang paling dominan menurun adalah rasio $\mathrm{X} 4$ yang mana pada tahun sebelumnya meningkat begitu besar.

\section{p. Koperasi Kelubagolit}

Tabel 3.16

Hasil Perhitungan Z-Score

Koperasi Kelubagolit Tahun 2015-2017

\begin{tabular}{|l|l|l|l|}
\hline \multicolumn{1}{|c|}{ Rasio } & \multicolumn{1}{|c|}{$\mathbf{2 0 1 5}$} & \multicolumn{1}{c|}{$\mathbf{2 0 1 6}$} & \multicolumn{1}{c|}{$\mathbf{2 0 1 7}$} \\
\hline $\mathrm{X} 1$ & 0,1314 & 0,2056 & 0,4410 \\
\hline $\mathrm{X} 2$ & 0,0018 & 0,0081 & 0,0125 \\
\hline $\mathrm{X} 3$ & 0,0037 & 0,0097 & 0,0153 \\
\hline $\mathrm{X} 4$ & 0,1839 & 0,1821 & 0,1921 \\
\hline Z-Score & 1,091 & 1,631 & 3,237 \\
\hline
\end{tabular}

Sumber: data diolah, 2019

Dari tabel 16. diatas, hasil perhitungan analisis Z-Score Koperasi Kelubagoit pada tahun 2015 sebesar 1,091 dan pada tahun 2016 mengalami peningkatan sebesar 1,631 dan koperasi Kelubagolit masuk dalam kategori gray area. Hal ini di sebabkan menurunnya nilai $\mathrm{X} 4$ yang mana rasio $\mathrm{X} 4$ ini sangat berpengaruh terhadap efektif atau tidaknya kemampuan koperasi dalam memenuhi kewajibannya. Sedangkan rasio pada X1, X2, dan X3 mengalami peningkatan. Sedangkan ditahun 2017 koperasi berhasil keluar dari zona gray area dan masuk dalam kategori sehat dengan nilai Z-Score 3,237 karena semua rasio mengalami peningkatan. Rasio yang mendominasi peningkatan adalah rasio $\mathrm{X} 1$ yang menggambarkan bahwa koperasi terus meningkatkan modal kerja bersih yang dimiliki koperasi.

\section{Hasil Prediksi Kebangkrutan Pada Koperasi}

Untuk menentukan nilai Z-Score pada setiap koperasi, maka dihitung seluruh rasio keuangan koperasi yang terdapat di sampel penelitian dengan rumus Altman $Z$ - Score. Setelah menghitung nilai $Z$ Score, maka diklasifikasikan koperasi tersebut dalam keadaan sehat, gray area dan bangkrut dengan hasil perhitungan sebagai berikut:

Berdasarkan semua tabel di atas menunjukkan bahwa dari 16 koperasi kredit sewilayah Puskopdit Swadaya Utama yang menjadi sampel penelitian yang dihitung dengan menggunakan model altman ZScore terdapat beberapa koperasi kredit yang dalam tahun 2015-2017 masuk dalam kondisi sehat, gray area, bangkrut, dan berfluktuatif

\section{Pembahasan}




\section{Jurnal Akuntansi dan Pajak, 21 (01), 2020, 67}

Rasio yang paling banyak mempengaruhi terjadinya penurunan nilai $Z$ - Score adalah rasio modal kerja terhadap total aktiva (X1) dan rasio nilai buku ekuitas terhadap total hutang (X4). Koperasi harus lebih meningkatkan modal kerja bersih dari seluruh aktiva yang dimiliki serta sejauh mana aktiva koperasi dibiayai dari hutang. Artinya berapa besar beban hutang yang ditanggung koperasi dibandingkan dengan aktivanya. Selain itu juga, faktor yang mempengaruhi bangkrut atau tidaknya sebuah koperasi ditentukan dengan cara penyajian laporan keuangan apakah sesuai dengan standar SAK ETAP atau tidak.

Koperasi-koperasi kredit sewilayah Puskopdit Swadaya Utama yang dijadikan sampel penelitian berjumlah 16 koperasi merupakan koperasi dalam ukuran besar maupun kecil yang memiliki total asset lebih dari 1 milyar rupiah ataupun kurang dari 1 milyar rupiah, namun jumlah asset tidak menjamin koperasi dalam kondisi aman atau sehat. Lamanya koperasi berdiri dan pengalaman koperasi selama bertahun-tahun yang mampu mejadikan koperasi lebih berkompeten karena memiliki pengalaman yang lebih banyak dalam menangani masalah koperasi. Koperasi dengan umur yang lama lebih baik dalam mengelola kinerja keuangannya sehingga nilai $Z$ Score koperasi cenderung lebih tinggi jika dibandingkan dengan koperasi yang baru berdiri. Hasil perhitungan prediksi kebangkrutan dengan menggunakan model Altman Z-Score pada 16 koperasi kredit sewilayah Puskopdit Swadaya Utama menunjukkan hasil yang berbeda-beda, ada yang masuk dalam kategori sehat, kategori gray area, dan kategori bangkrut. Analisis setiap kategori dapat di jelaskan sebagai berikut:

\section{a. Kategori Sehat}

Dari hasil penelitian koperasi yang masuk dalam kategori sehat yang mana nilai $\mathrm{Zi}>2,6$ selama tiga tahun pengamatan berturut-turut dari tahun 2015, 2016, dan 2017 terdapat 6 koperasi adalah koperasi Obor Mas, Tuke Jung, Ortal, Ladang, Bintang Timur, dan Serba Te. Dari keenam koperasi yang berada dalam kondisi sehat selama tiga tahun berturut-turut dengan nilai $Z$-Score tertinggi adalah koperasi Serba Te. Koperasi ini bertahan secara konsisten selama tiga tahun berturut-turut dan memiliki nilai $\mathrm{Z}$ tertinggi dibandingkan koperasi lainnya.

Koperasi yang masuk dalam kategori sehat selama tiga tahun berturut-turut yang berarti koperasi memiliki peluang kecil dalam masalah kebangkrutan.
Koperasi yang masuk dalam kategori sehat di sebabkan karena memiliki kinerja keuangan yang baik dan tercermin dalam peningkatan kemampuan modal kerja bersih koperasi, peningkatan dalam menghasilkan SHU bersih maupun SHU sebelum pajak, serta memiliki kemampuan untuk memenuhi kewajiban- kewajibannya baik jangka pendek maupun jangka panjang.

Koperasi Kelubagolit adalah koperasi yang pada dua tahun berturut-turut yaitu tahun 2015 dan 2016 berada dalam kondisi gray area. Namun pada tahun 2017 berhasil meningkatkan posisi koperasi menjadi sehat. Peningkatan Z-Score ini terjadi karena pada tahun 2017 koperasi berhasil melakukan perbaikan kinerja sehingga koperasi ini berhasil memperoleh kenaikan dengan signifikan hingga dapat menempati posisi sehat dengan Z-Score sebesar 3,237. Melihat kenaikan nilai $Z$-Score yang cukup signifikan ini bukan tidak mungkin koperasi Kelubagolit dapat mencapai tingkat kesehatan yang semakin membaik apabila pihak manajemen koperasi dapat terus konsisten dalam melakukan perbaikan dari tahun ke tahun, sehingga koperasi tetap mempertahankan keuangannya agar terus berada dalam posisi keuangan yang sehat.

\section{b. Kategori Gray Area}

Dari hasil penelitian dengan menggunakan model Altman Z-Score terdapat koperasi kredit sewilayah Puskopdit Swadaya Utama yang masuk dalam kondisi gray area selama tiga tahun berturutturut yaitu dari tahun 2015-2017 adalah koperasi Tuke Ler, Sube Huter, Hiro Heling, Bina Pertiwi, dan Surya Sakti. Nilai Z-Score diantara 1,12,6 menunjukkan kondisi gray area artinya koperasi perlu mengantisipasi adanya potensi kebangkrutan dengan meningkatkan kinerja keuangan agar koperasi berada dalam kondisi yang aman atau sehat.

Koperasi yang masuk dalam kondisi gray area selama tiga tahun berturut-turut di sebabkan karena kinerja keuangan yang ditunjukkan dengan melemahnya sejumlah rasio keuangan. Kondisi ini menunjukkan bahwa koperasi sedang menghadapi masalah keuangan yang cukup serius, dimana apabila koperasi tidak segera melakukan perbaikan, koperasi mungkin akan menghadapi ancaman kebangkrutan pada jangka pendek ataupun jangka panjang.

Koperasi San Dominggo pada tahun 2015 dan 2016 berada dalam kondisi bangkrut atau financial distress, namun pada tahun 2017 berhasil 


\section{Jurnal Akuntansi dan Pajak, 21 (01), 2020, 68}

meningkatkan koperasinya dan masuk dalam kategori gray area tetapi nilai Z-Score yang di peroleh sangat tipis berdekatan dengan batas klasifikasi potensial bangkrut. Koperasi San Dominggo selama dua tahun mengalami kesulitan keuangan, koperasi terus memaksimalkan kinerjanya sehingga pada tahun ketiga berhasil keluar dari zona kebangkrutan. Namun koperasi masih harus terus berusaha lebih agar koperasi bisa benar- benar masuk dalam kategori sehat.

\section{c. Kategori Bangkrut}

Hasil analisis penelitian juga diketahui terdapat 2 koperasi yang mengalami kondisi bangkrut selama tiga tahun berturut-turut, yaitu koperasi Ankara dan Remaja Hokeng. Nilai Z-Score $<1,1$ menunjukkan kondisi bangkrut yang berpotensi mengakibatkan koperasi tersebut akan mengalami kebangkrutan di masa mendatang, sehingga diperlukan langkah yang tepat untuk memperbaiki kondisi keuangan koperasi. Koperasi yang berada dalam kondisi bangkrut maka pengelola harus lebih berhati-hati dan harus melakukan perbaikan secepatnya agar tidak mengalami kebangkrutan di periode berikutnya.

Koperasi Plelu Meluk pada tahun 2015 berada dalam posisi gray area dengan nilai Z-Score 1,435. Di tahun berikutnya koperasi terus mengalami penurunan hingga menempati posisi bangkrut dengan Z-Score sebesar 1,032. Penurunan terjadi karena semua rasio $\mathrm{X}$ mengalami penurunan, hal ini membuktikan bahwa koperasi masih belum secara maksimal untuk mengelola seluruh elemen keuangannya sehingga dapat berfungsi lebih baik agar terhindar dari kebangkrutan. Hingga tahun 2017, kesehatan koperasi ini terus mengalami penurunan yakni sebesar 1,010 yang mana tetap berada dalam posisi bangkrut.

Kondisi ini menunjukkan perlunya upaya evaluasi dari pihak manajemen untuk mengetahui permasalahan atau kesalahan dalam pengambilan keputusan yang telah diambil sehingga koperasi masih terjebak dalam kondisi distress. Melalui upaya evaluasi diharapkan koperasi dapat memperbaiki kondisi finansialnya sehingga dapat menghasilkan kinerja yang lebih baik.

\section{KESIMPULAN}

Hasil penelitian menyimpulkan bahwa dari perhitungan Z-Score koperasi-koperasi kredit sewilayah Puskopdit Swadaya Utama yang menjadi sampel penelitian selama tiga tahun yaitu tahun 20152017 terdapat koperasi yang mengalami peningkatan yang konsisten, ada yang mengalami penurunan yang konsisten dan ada juga yang tetap. Koperasi yang berada pada kondisi sehat selama tahun pengamatan yaitu tahun 2015-2017 adalah koperasi Obor Mas, Tuke Jung, Ortal, Ladang, Bintang Timur, dan Serba Te. Dan pada tahun 2015 dan 2016 koperasi Kelubagolit masuk dalam kategori gray area, namun tahun 2017 koperasi ini masuk dalam kategori sehat.

Di samping itu juga, terdapat koperasi yang berada pada kondisi gray area selama tiga tahun berturut-turut dari tahun 2015, 2016, dan 2017 adalah koperasi Tuke Ler, Sube Huter, Hiro Heling, Bina Pertiwi, dan Surya Sakti. Pada tahun 2015 dan 2016 koperasi San Dominggo masuk dalam kategori bangkrut dan pada tahun 2017 koperasi tersebut berhasil masuk dalam kategori gray area.

Koperasi yang berada pada kondisi distress pada tahun pengamatan yaitu tahun 2015, 2016, dan 2017 dimana kondisi ini menunjukkan potensi kebangkrutan pada koperasi adalah koperasi Ankara dan Remaja Hokeng. Pada tahun 2018 koperasi Remaja Hokeng tidak mampu keluar dari zona bangkrut dan akhirnya memutuskan untuk melakukan amalgamasi dengan koperasi Mitan Gitan. Dari hasil analisis prediksi kebangkrutan tersebut dengan model Altman (Z-Score) membuktikan bahwa model tersebut mampu memprediksi kebangkrutan koperasi. Pada tahun 2015 koperasi Plelu Meluk masuk dalam kategori gray area, tetapi pada tahun berikutnya yaitu tahun 2016 hingga 2017 kinerja koperasi ini terus menurun dan masuk dalam kategori bangkrut. Koperasi yang berada dalam kondisi bangkrut atau distress maka pengelola harus lebih berhati-hati dan harus melakukan perbaikan secepatnya agar tidak mengalami kebangkrutan di periode berikutnya.

Adapun saran yang bisa diberikan dalam penelitian ini : Diharapkan dapat memberi manfaat bagi pihak pengurus, pengawas, maupun manajer koperasi sebagai gambaran informasi serta acuan pertimbangan dalam pengambilan keputusan keuangan. Koperasi yang masuk dalam kategori sehat dapat mempertahankan kinerja saat ini serta meningkatkannya di masa yang akan datang dengan cara peningkatan kemampuan modal kerja bersih koperasi, peningkatan dalam menghasilkan SHU bersih maupun SHU sebelum pajak, serta memiliki kemampuan untuk memenuhi kewajibankewajibannya baik jangka pendek maupun jangka 
panjang. Koperasi yang berada dalam kategori gray area harus meningkatkan kinerja koperasi dengan salah satu cara yaitu meningkatkan simpanan wajib dan menurunkan piutang macet. Sedangkan untuk koperasi yang berada dalam kategori bangkrut dapat mengambil langkah-langkah yang dirasa tepat untuk mengatasi kondisi keuangan koperasi yang bermasalah, seperti lebih memperhatikan pengelolaan asset yang dimiliki, manajemen koperasi harus terampil dalam pengambilan keputusan, dan penyajian laporan keuangan harus sesuai dengan SAK ETAP.

\section{REFERENSI}

Alif Fikri. 2017. Analisis Prediksi Kebangkrutan Dengan Menggunakan Metode Altman ZScore Pada Perusahaan Manufaktur Yang Terdaftar di BEI. Yogyakarta: Fakultas Ekonomi Universitas Islam Indonesia, Diakses melaluihttps://dspace.uii.ac.id/bitstream/handle/1 23456789/5570/SKRIPSI\%20-

\%20ALIF\%20FIKRI\%20ALIM\%20-

$\% 2013311238$.pdf? sequence $=1$

Baswir, Revrisond. 2000. Koperasi Indonesia. Edisi Pertama. Yogakarta: BPFE.

Brigham dan Houston. 2001. Manajemen Keuangan. Edisi Delapan. Jakarta: Salemba Empat.

Burhanuddin, Rizky Amalia. 2015. Analisis Penggunaan Metode Altman Z-Score Untuk Mengetahui Potensi Terjadinya Financial Distress Pada Perusahaan Manufaktur Sektor Industri Dasar dan Kimia Sub Sektor Semen Periode 2009-2013. Makassar: Fakultas Ekonomi dan Bisnis Universitas Hasanuddin.

Claudio, Anastasya dan Wiston Pontoh. 2015. Analisis Model Altman Z-Score Dalam Mengukur Kinerja Keuangan Untuk Memprediksi Kebangkrutan Pada Perusahaan Manufaktur Sektor Industri Barang Konsumsi Di Bursa Efek Indonesia (BEI) Periode 2010- 2014. Jurnal Accountability.

Darsono dan Ashari. 2005. Pedoman Praktis Memahami Laporan Keuangan. Yogyakarta: Andi.

Fahmi, Irfan. 2011. Analisis Laporan Keuangan. Bandung: Alfabeta.

Gamayuni, Rindu Rika. 2011. Analisis Ketepatan Model Altman Sebagai Alat Untuk Memprediksi Kebangkrutan (Studi Empiris Pada Perusahaan Manufaktur di BEI). Jurnal Akuntansi dan Keuangan.
Gill, James O., dan Chantton Moira. Tanpa tahun. Memahami Laporan Keuangan. Terjemahan oleh Dwi Prabaningtyas. 2006. Jakarta: PPM.

Hanafi, Mamduh. M. 2003. Analisis Laporan Keuangan. Yogyakarta: UPP AMK YKPN.

Harahap, Sofyan Syafri. 2011. Analisis Kritis Atas Laporan Keuangan. Jakarta: Raja Grafindo Persada.

Hery. 2016. Analisis Laporan keuangan. Jakarta: Grasindo.

Ikatan Akuntan Indonesia. 2009. Standar Akuntansi Keuangan. Jakarta: Salemba Empat.

$\begin{array}{llr}\text { Akuntansi Keuangan } & \text { Entitas } & \text { Tandar } \\ \text { Akuntanbilitas Publik. Jakarta: Salemba Empat. }\end{array}$
Akuntansi Keuangan. Jakarta: Salemba Empat. Jogiyanto, H.M. 2013. Teori Portofolio dan Analisis Investasi. Yogyakarta: BPFE.

Kamaludin dan Indriani. 2012. Manajemen Keuangan. Edisi Revisi. Bandung: CV. Mandar Maju.

Kartikawati, Sinta. 2009. Analisis Z-Score Dalam Mengukur Kinerja Keuangan untuk Memprediksi Kebangkrutan Pada Tujuh Perusahaan Manufaktur di Bursa Efek Jakarta Tahun 2001-2006. E-Journal Ekonomi hal 2544.

Kasmir. 2011. Analisis Laporan Keuangan. Jakarta: Rajawali Pers.

Kurnia, Okta Dwi, Rustam Hidayat, dan Nila F. Nuzula. 2013. Analisis Laporan Keuangan Dalam Memprediksi Kebangkrutan Pada Perusahaan Manufaktur (Studi pada 3 Perusahaan Plastik dan Kemasan yang Listing dan 1 Perusahaan Delisting di BEI). Jurnal Administrasi Bisnis. Diakses melalui https://docplayer.info/amp/156730379-Analisislaporan-keuangan-dalam-memprediksikebangkrutan-pada-perusahaan-manufaktur.html Kneefel, Stevany Anthoneta dan Yunita Mandagie. 2014. Analisis Z-Score Pada Perusahaan Food \& Beverages yang Terdaftar di BEI Periode 2011 2013. Jurnal Ekonomi, Manajamen, Bisnis dan Akuntansi.

Lesmana, Rico. 2003. Pedoman Menilai Kinerja Untuk Perusahaan Tbk, Yayasan, BUMN, BUMD, dan Organisasi Lainnya. Edisi Pertama. Jakarta: Elex Media Komputindo.

Marcelina, Tri A. dan Willy S.Y. 2013. Prediksi Kebangkrutan Menggunakan Metode Z-Score dan Pengaruhnya Terhadap Harga Saham Pada 


\section{Jurnal Akuntansi dan Pajak, 21 (01), 2020, 70}

Perusahaan Transportasi yang Terdaftar di Bursa Efek Indonesia Tahun 2008-2012. E-Proceeding of Management.

Maheni, Ni Komang. 2017. Analisis Faktor Penyebab Bangkitnya Koperasi dari Kebangkrutan (Studi Kasus Pada Koperasi Jasa Puspa Sari Perdana Buleleng). E-Journal Akuntansi.

Muljono, Djoko. 2015. Buku Pintar Akuntansi Perbankan dan Lembaga Keuangan Syariah. Yogyakarta: Andi.

Munawir. 2002. Analisis Laporan Keuangan. Yogyakarta: Liberty.

Ningsih, S., \& Permatasari, F. F. (2018). Analysis Method of Altman Z Score Modifications to Predict Financial Distress on The Company Go Public Sub Sector of The Automotive and Components. International Journal of Economics, Business and Accounting Research (IJEBAR), 2(03).

Nugroho, Mokhamad I. Dwi. 2011. Analisis Prediksi Financial Distress Dengan Menggunakan Model Altman Modifikasi. Semarang: Fakultas Ekonomi dan Bisnis Universitas Diponegoro.

Oktavia, Reni. 2013. Mendeteksi Kebangkrutan Perusahaan dengan Menggunakan Metode ZScore (Studi Kasus Pada PT Bank BNI Syariah). Thesis AIN Sunan Ampel Surabaya.

Pangkey Pricilia C., Ivonne S. Saerang, dan Joubert B.M. 2017. Analisis Prediksi Kebangkrutan dengan Menggunakan Metode Altman Z-Score dan Metode Zmijewski Pada Perusahaan Bangkrut yang Pernah Go Public di BEI. Jurnal Ekonomi, Manajamen, Bisnis dan Akuntansi.

Patunrui, Katarina I. A. dan Sri Yati. 2016. Analisis Penilaian Financial Distress Menggunakan Model Altman Z-Score Pada Perusahaan Farmasi yang Terdaftar di BEI Periode 20132015. Jurnal Akuntansi, Ekonomi, dan Manajemen Bisnis.

Marcelinda, Sheilly O., Hadi Paramu, dan Novi Puspitasari. 2014. Analisis Akurasi Prediksi Model Altman Z- Score Pada Perusahaan Manufaktur yang Terdaftar di BEI. E-Journal Ekonomi Bisnis dan Akuntansi.

Prihadi, Toto. 2010. Analisis Laporan Keuangan Teori dan Aplikasi. Cetakan Pertama. Jakarta: PPM.

Ramadhani, Ayu S. dan Niki Lukviarman. 2009. Perbandingan Analisis Prediksi Kebangkrutan Menggunakan Model Altman Pertama, Altman Revisi, dan Altman Modifikasi Dengan Ukuran dan Umur Perusahaan Sebagai Variabel Penjelas (Studi Pada Perusahaan Manufaktur yang Terdaftar di Bursa Efek Indonesia). Jurnal Siasat
Bisnis, (Online), Vol. 13, No. 1, (https://journal.uii.ac.id diakses 20 februari 2019).

Rudianto. 2010. Akuntansi Koperasi. Edisi Kedua. Jakarta: Erlangga.

Sekaran, Uma. 2006. Metodologi Penelitian Untuk Bisnis. Edisi Keempat. Jakarta: Salemba.

Sinaga, Bernike. 2012. Analisis Laporan Keuangan Untuk Memprediksi Financial Distress Pada Kopdit/CU. Cinta Mulia Pematangsiantar. Jurnal Sultanist Manajamen dan Keuangan.

Sitio, Arifin dan Halomoan Tamba. 2001. Koperasi Teori dan Praktik. Jakarta: Erlangga.

Soemitra, Andri. 2009. Bank dan Lembaga Keuangan Syariah. Edisi Pertama. Jakarta: Kencana.

Sugiyono. 2008. Statistik Untuk Penelitian.

Bandung: Alfabeta.

--------. 2012. Metode Penelitian Kuantitatif Kualitatif dan $R \& D$. Bandung: Alfabeta.

-------, 2015. Metode Penelitian Pendidikan (Pendekatan Kuantitatif, Kualitatif, dan R\&D). Bandung: Alfabeta.

Suharto. 2015. Analisis Prediksi Financial Distress dan Kebangkrutan Pada PerusahaanPerusahaan yang Listing Dalam Daftar Efek Syariah dengan Model Z-Score. Semarang: Fakultas Ekonomi dan Bisnis Universitas Islam Negeri Semarang.

Supardi dan Sri Mastuti. 2003. Validitas Penggunaan Z-Score Altman untuk Menilai Kebangkrutan Pada Perusahaan Perbankan Go Public di BEJ. Jurnal Akuntansi, Manajemen dan Sistem Informasi.

Suyanto dan Nurhadi. 2013. IPS Ekonomi.

Yogyakarta: Erlangga.

Syafrida, Hani. 2015. Teknik Analisa Laporan Keuangan. Medan: UMSU PRESS.

Undang-Undang Republik Indonesia Nomor

25 Tahun 1992 tentang Perkoperasian. 2012. Jakarta:

Departemen Keuangan Republik Indonesia.

Undang-Undang Republik Indonesia Nomor

17 Tahun 2012 tentang Perkoperasian. 2012. Jakarta: Departemen Keuangan Republik Indonesia.

Widiyanti, Ninik dan Sunindhia. 2009. Koperasi dan Perekonomian Indonesia. Jakarta: Rineka Cipta. -----, Anita Tri, Supri Wahyudi, dan Nik Amah. 2015. Analisis Rasio Altman Modifikasi Pada Prediksi Kebangkrutan Perusahaan Property dan Real Estate yang Terdaftar di Bursa Efek Indonesia. Jurnal Akuntansi dan Pendidan 
Jurnal Akuntansi dan Pajak, 21 (01), 2020, 71 